\title{
USPIO enhanced 4D flow imaging of the mouse cardiovascular system at 7T with an ultrashort echo time sequence
}

\author{
Aurélien J Trotier*, Charles Castets, William Lefrançois, Jean-Michel Franconi, Eric Thiaudière, Sylvain Miraux \\ From 18th Annual SCMR Scientific Sessions \\ Nice, France. 4-7 February 2015
}

\section{Background}

Time resolved phase contrast imaging is hardly used in small animal studies due to a lack of signal-to-noise ratio. Some studies were performed in 2D and one publication (Janiczek et al, MRM 2011) reported flow measurement in mouse aortic arch in 3D due to the use of a thin excitation slab and high Time-Of-Flight (TOF) effect. However, this strategy is not applicable on the whole cardiopulmonary system. To overcome this problem we proposed to combined Ultra-short Echo Time sequence with an injection of Ultra Small Particles of Iron Oxide (USPIO) to generate a stable, positive and high blood signal.

The method was first validated on phantom and then applied on the whole cardiopulmonary system of normal mice.

\section{Methods}

The flow sequence was based on a 3D-cine non spatially selective UTE sequence $(\mathrm{TR} / \mathrm{TE}=6 / 0.031 \mathrm{~ms})$. Flow encoding gradient (duration : $0.540 \mathrm{~ms}$, Hadamard encoding method) were inserted between the RF pulse and imaging gradient, resulting in an echo time of $0.571 \mathrm{~ms}$. The sequence was compared to a standard Phase Contrast cartesian FLASH sequence $(\mathrm{TR} / \mathrm{TE}=2.3 / 6 \mathrm{~ms})$.

Flow measurements were performed on a rectilinear tube at 7T with an imposed average velocity of $25,8 \mathrm{~cm} / \mathrm{s}$. The tube was next fulfilled with various solution of $\mathrm{MnCl} 2$ $(0 / 1 / 2 / 4 / 6 / 8 \mathrm{mM})$ to evaluate the robustness of the method as a function of r2 and r2\%.

4D flow imaging of the mouse cardiovascular system was performed with a $100 \mu \mathrm{L}$ injection of USPIO at a dose of $100 \mu \mathrm{mol} \mathrm{Fe} / \mathrm{kg}$ with a ECG triggered UTE

\footnotetext{
Centre de Résonance Magnétique des Systèmes Biologiques, Bordeaux,
} France

\section{Results}

On phantom, the measured velocity was in accordance with the imposed flow, using the UTE sequence, at each $\mathrm{MnCl} 2$ concentration, whereas an error superior to $5 \mathrm{~cm} / \mathrm{s}$ was observed with the FLASH sequence when $\mathrm{MnCl} 2$ concentration was higher than $1 \mathrm{mM}$.

On the mouse heart, UTE images were obtained without flow dephasing artefacts on the whole heart and in major vessels (aortic cross, carotids, pulmonary arteries, descending aorta). A blood velocity vector map in the aortic cross is presented in figure 1 and can be obtained in all vessels of the mouse.

\section{Conclusions}

We have demonstrated that combining the injection of iron nanoparticles with 3D Time-Resolved Phase Contrast UTE sequences generated a strong positive contrast between blood and surrounding tissues. These properties were exploited to quantify blood flow velocity of the cardiovascular system in small animals at high magnetic fields with a high spatial $(<(200 \mu \mathrm{m}) 3)$ and temporal resolution $(16 \mathrm{~ms})$. This approach might be useful to assess flow velocities and flow velocity variations in cardio-vascular disease models.

\section{Funding}

This work was supported by a public grant, Translational Research and Advanced Imaging Laboratory, which is part of the French National Research Agency's Investments for the Future Program ("NewFISP"; ANR10-LABX-57). 

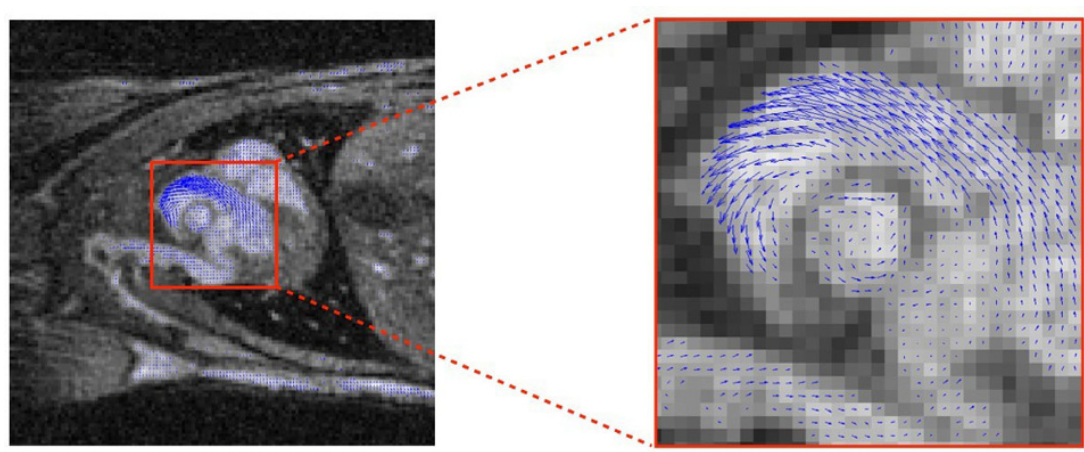

Figure 1 Extracted coronal slice with corresponding flow velocities vectors on heart.

Published: 3 February 2015

doi:10.1186/1532-429X-17-S1-070

Cite this article as: Trotier et al:: USPIO enhanced 4D flow imaging of

the mouse cardiovascular system at 7T with an ultrashort echo time

sequence. Journal of Cardiovascular Magnetic Resonance 2015 17(Suppl 1):

070 .

Submit your next manuscript to BioMed Central and take full advantage of:

- Convenient online submission

- Thorough peer review

- No space constraints or color figure charges

- Immediate publication on acceptance

- Inclusion in PubMed, CAS, Scopus and Google Scholar

- Research which is freely available for redistribution

Submit your manuscript at www.biomedcentral.com/submit 